\title{
Remarkable Identification of Rohi Derawar Fort
}

\author{
Nusrat Bibi* \\ * Department of Textile Design, University College of Art \& Design, Faculty of Arts, The Islamia University of Bahawalpur, Pakistan \\ DOI: 10.29322/IJSRP.11.10.2021.p11831 \\ http://dx.doi.org/10.29322/IJSRP.11.10.2021.p11831
}

\begin{abstract}
Derawar Fort is a remarkable identification of Rohi Cholistan. Derawar Fort was built in AD 900 known as Dera Rawal. Derawar Fort is a giant four-sided fortress in Ahmadpur East Tehsil, Punjab, Pakistan. About one hundred ten km south of the town of Bahawalpur, the forty supporters of Derawar Fort are evident for numerous miles in the Rohi Cholistan Desert. When the Derawar Fort was built, all the towers of the fort were made of mud. Over time, the fort also saw its rise and fall. Then when the Nawab of Bahawalpur Khan 1 made it the capital of his state, then the Nawab of Bahawal Khan 1 constructed it with tile bricks. At the same time, it has its own identity in the world.
\end{abstract}

Index Terms- Monuments, Identification, History, Cholistan Desert, Architecture.

\section{INTRODUCTION}

$\mathrm{T}$ he fortress Derawar is among extraordinary forts of Cholistan which lies on historic river Hakra and $50 \mathrm{~km}$ from Tehsil Ahmadpur Sharqia. Its renowned fort was center stage among the Rajput and Daudputras Abbasai competitions during $18^{\text {th }}$ century. Its geo-strategic position at the center of the Cholistan desert made it a reserve for several leaders and their treasure hoards thus prompting the rulers of Jaisalmeer and Bahawalpur States to obtain it and opportunity it into state capital. The existing building is stated to have been built over the ruins of an ancient, preMuslim period fort. Derawar Fort was built in AD 900 by Dera Sidh-also known as Dera Rawal or simply Rawal, a scion of the Bhatti dynasty of Jaisalmer who constructed the fort with the consent of Jajia Bhattia, a Rajisthani prince. The castle was once at the beginning named after its founder, Dera Rawal, however with time, became acknowledged as Derawar Fort.

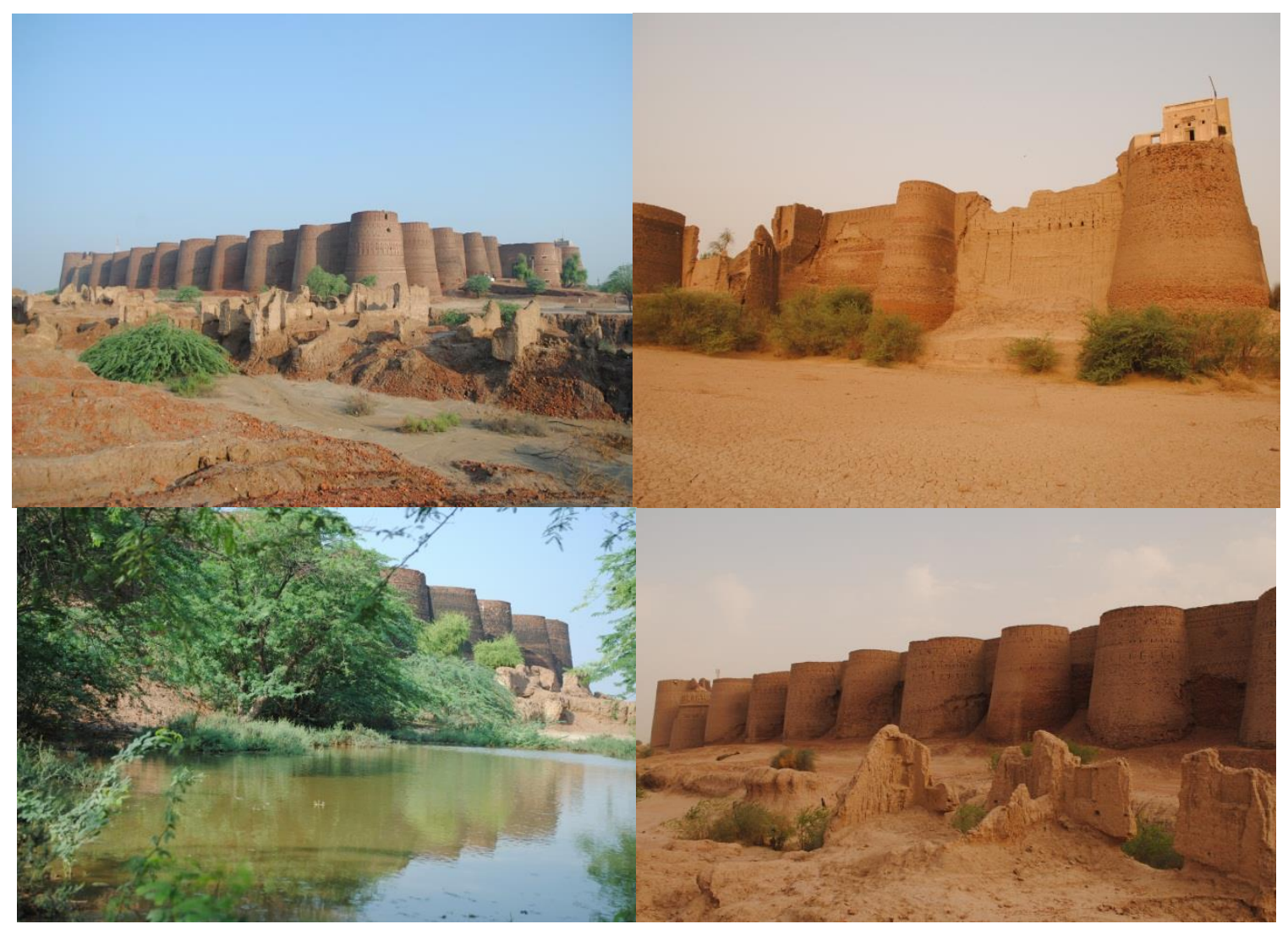


Ownership of the fortress frequently modified hands. During the Aryan era the warrior Sudasa, fought in opposition to the Aryans as nicely as non-Aryan took the control of Derawar Fort and its surrounding area?" Subsequently, when the Aryans engaged Jaisalmer, Derawar Fort kept on passing from one invading party to the next. Finally, Ameer Sadiq Muhammad Khan Abbasi I, founder of the Kingdom of Bahawalpur, seized Derawar Fort from the Sikh Ruler, Rawal Rai Singh, in AD 1733, supported by using the Governor of Multan, after a brutal battle. The castle remained in the control of the Abbasi family to era, was made capital in AD 1747 of the State until the foundling of
Bahawalpur by way of Ameer Bahawal Khan Abbai I and Derawar Fort flourished as way of its populace grew, schools, industrial centers, offices and headquarters of the country Camel Corps have been recognized within. Scarcity of water successively caused the fort's shape to decay and components of it to fall. Built on a high mound, Derawar Fort was once at the start blanketed by way of an outer fortification wall, only part of which remains. The fortress is square in plan, measuring $672 \mathrm{ft}$. across, and originally had a barrel-shaped roof. Entering to the bastion is complete a large wooden gate guarded by using a test submit on its

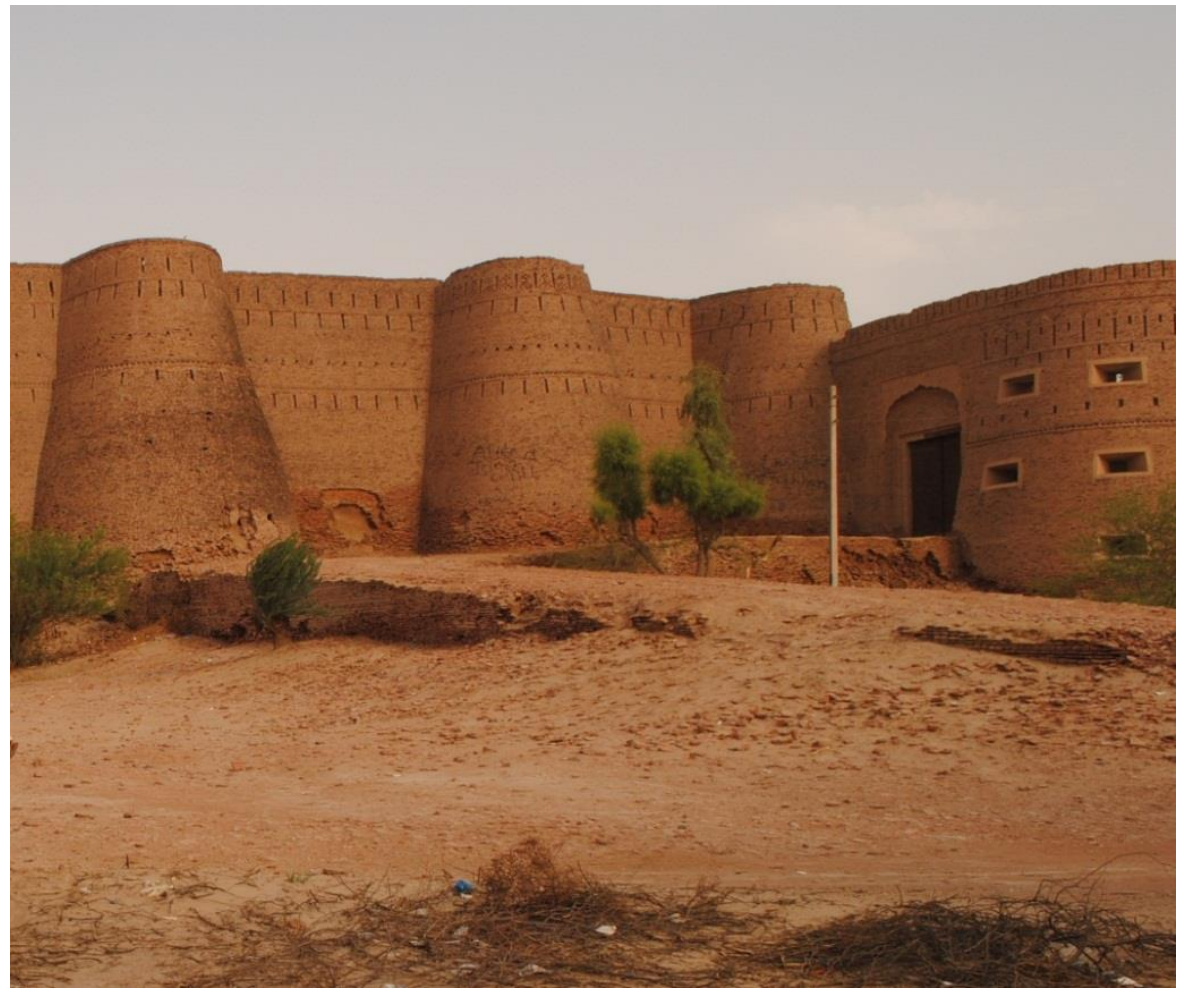

southern side. The gate itself is seventeenth $\mathrm{ft}$. excessive and has a width of 13 toes 8 inches. The gate opens into an arched passageway that is nearly $60 \mathrm{ft}$. in size and leads into the major plinth level inner the fort. The main fortification wall varies between 60 and $90 \mathrm{ft}$. in height and is supported by means of forty bastions. The nook bastions measure close to forty seven $\mathrm{ft}$. in diameter. 


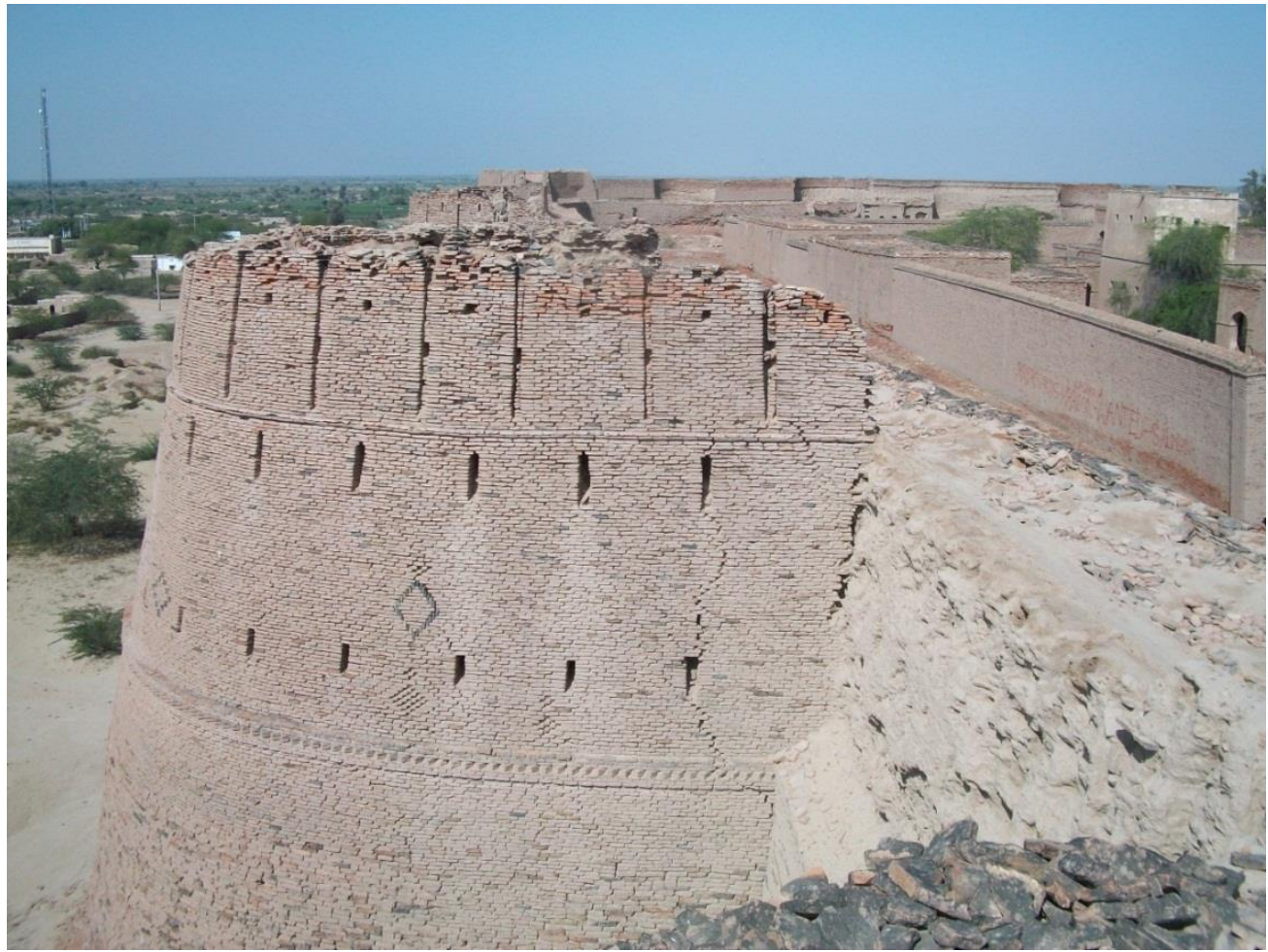

The surviving bastions display unique geometrical designs in brick-work nearly $15 \mathrm{ft}$. beneath their crests. At present, most of the bastions are intact. It is said that $1 / 2$ of them have been made of sun-dried brick and $1 / 2$ of burnt brick. The bricks used range in size from one bastion to the next; indicating that repairs and additions had been carried out from time to time."
The best possible bastion, recognized as Kakoha after its architect, is situated on the left façade of the most important entrance, and was as soon as famous as a venue for literary soirees." Still equally west are a number of visitor rooms at once earlier

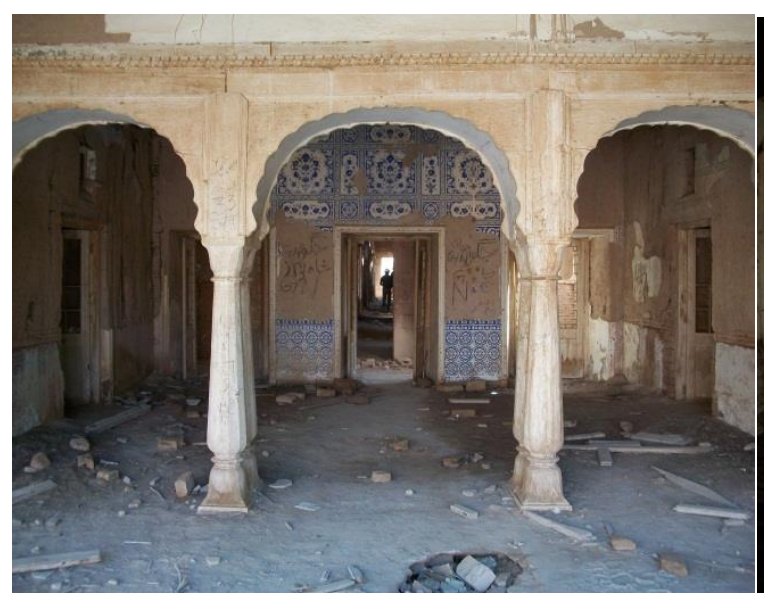

zenan khana. The visitor rooms are preceded by way of the Ameer's chamber with a veranda elegantly embellished with fresco work and three embellished arches. The room in the

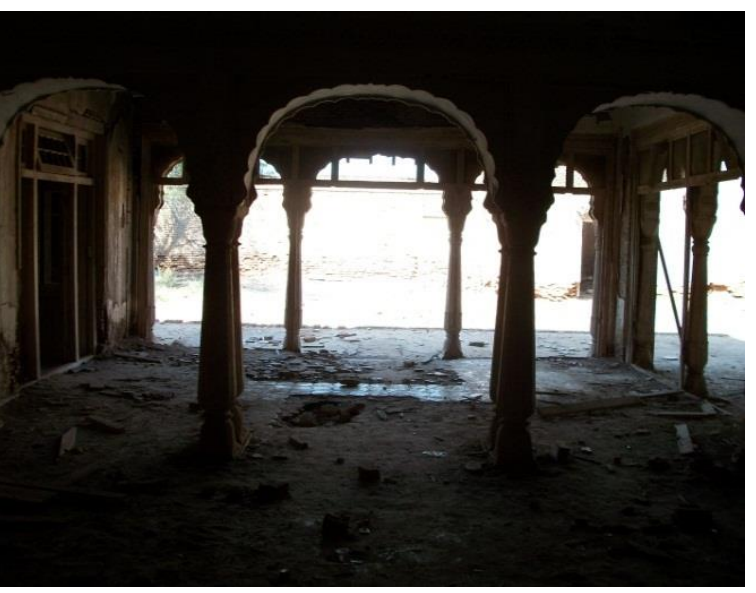

front leads to a hall that passes via the center of the visitor rooms. The residential quarter or families region is advanced via a large wooden door adorned with significant Carvi ngs; there is a mosque near the entrance to this area, marked with two small minarets. 


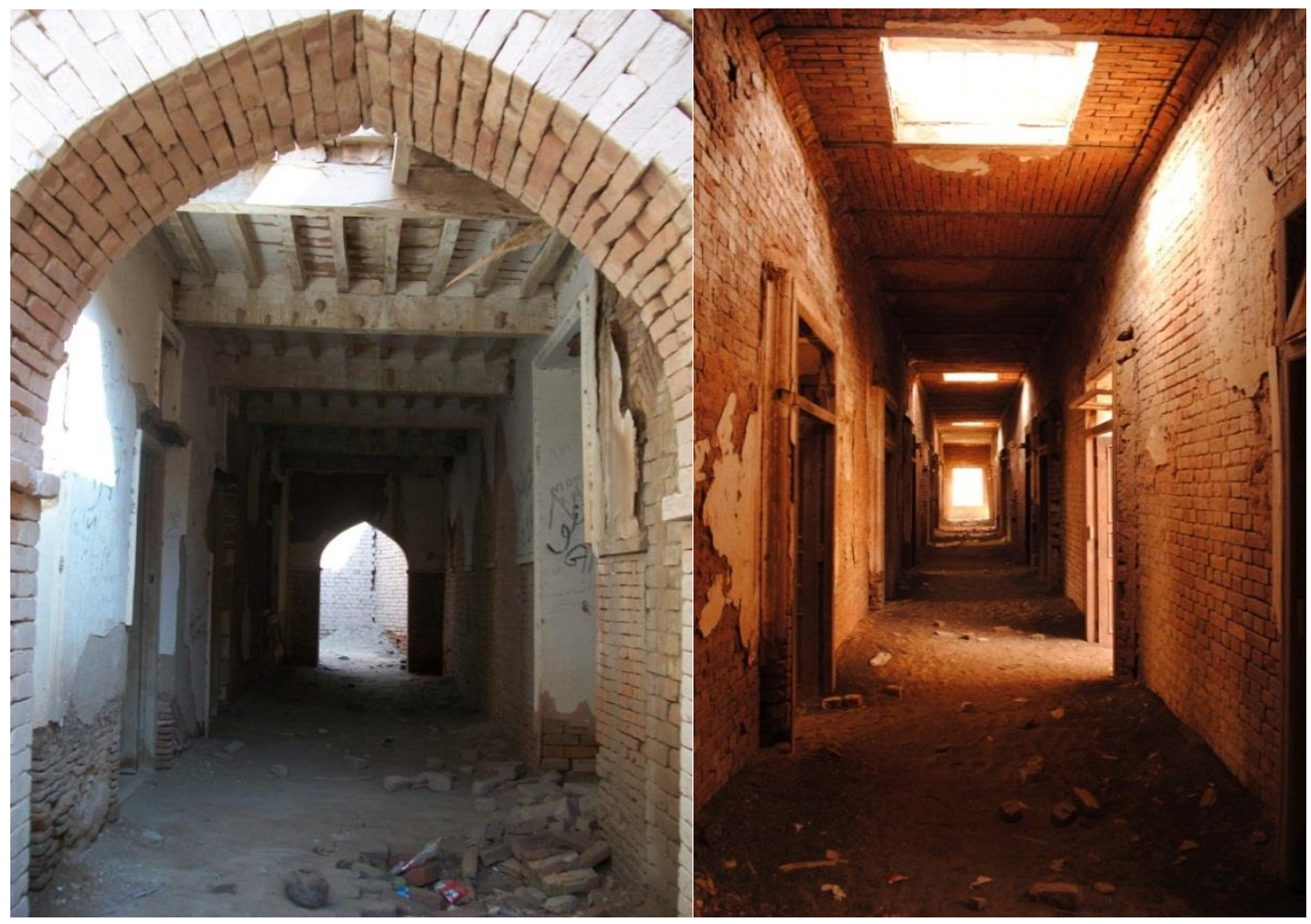

A corridor leads through the major zenan khana and the rooms on either aspect are bisected through a range of skylights. Each room has a fireplace and an attached washroom. The fresco work on the walls, even though need of restoration is nevertheless worth seeing. Towards the cease of this complex on the southern aspect is every other double-storey chamber belonging to the Ameer of Bahawalpur.

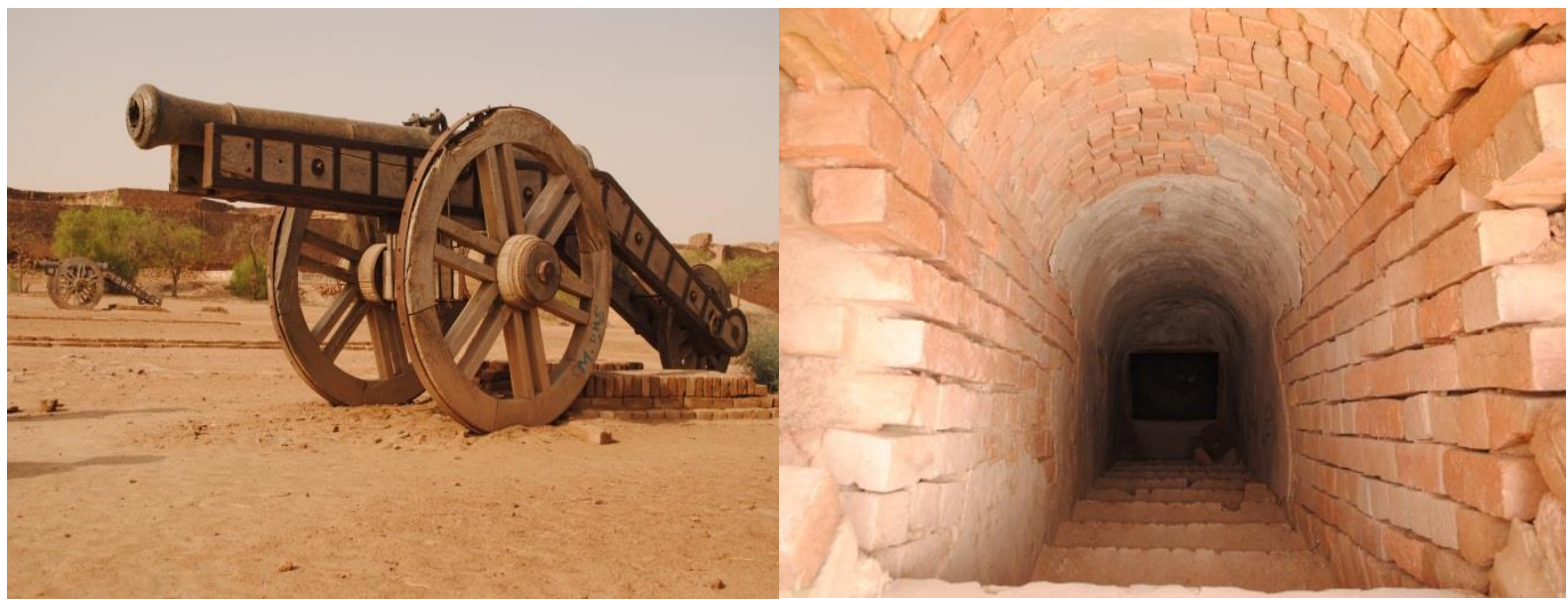




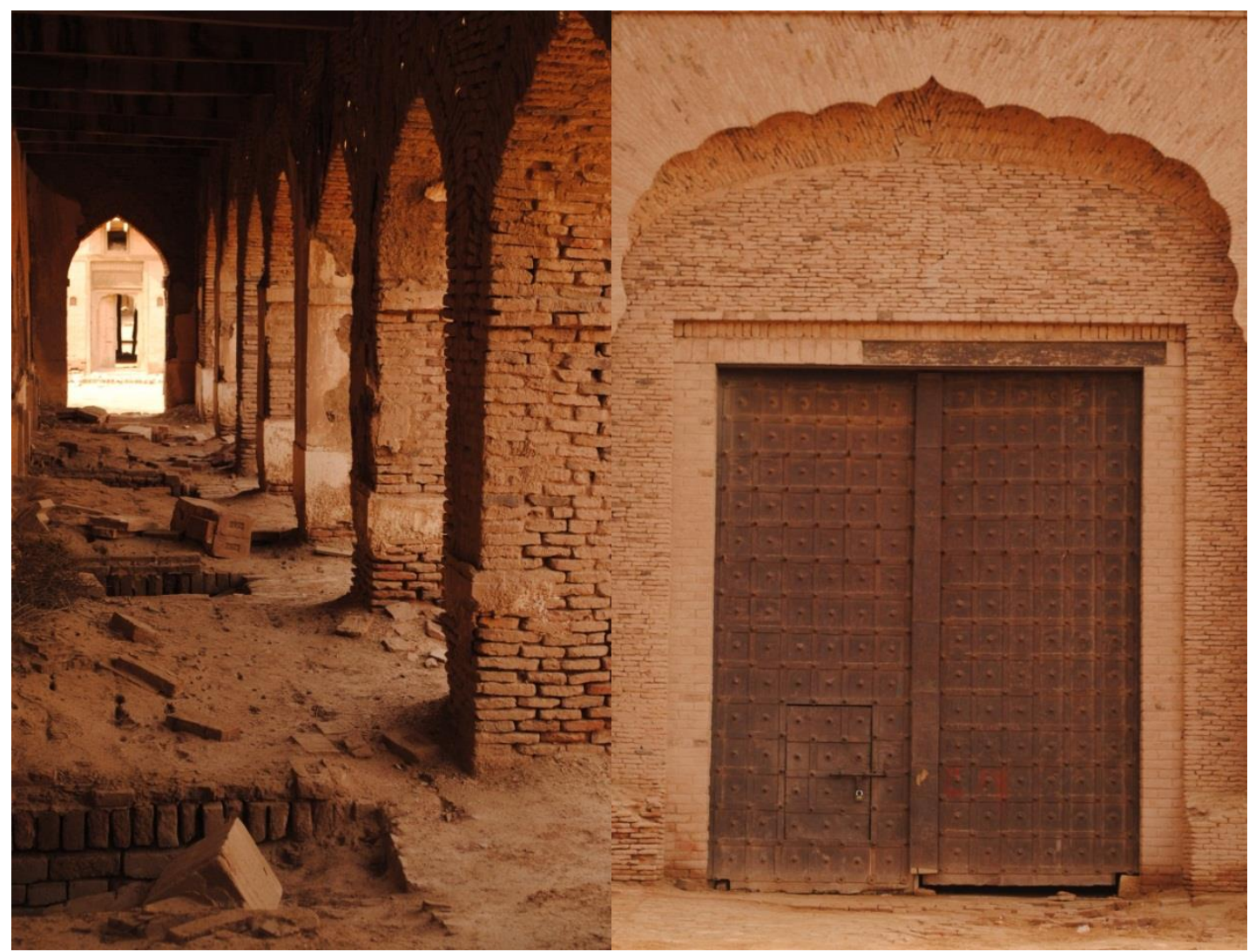

The zenan khana itself includes two similar buildings, uniquely linked with the aid of competency of openings, and enclosed by way of an unnecessary wall, components of which are still standing. Derawar is a great architectural masterpiece. Occupying the far south of Punjab, Cholistan is the largest desert in Pakistan, covering over 25,000 sq. kms area

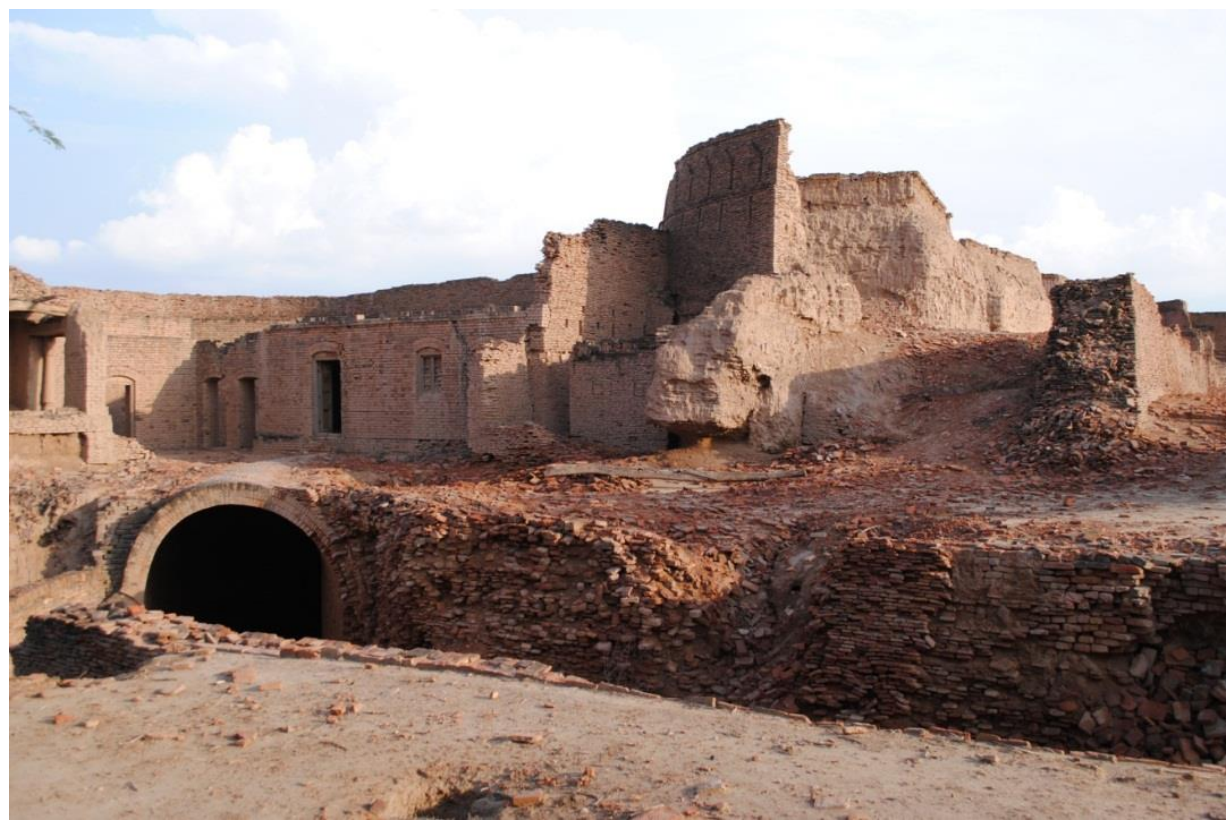




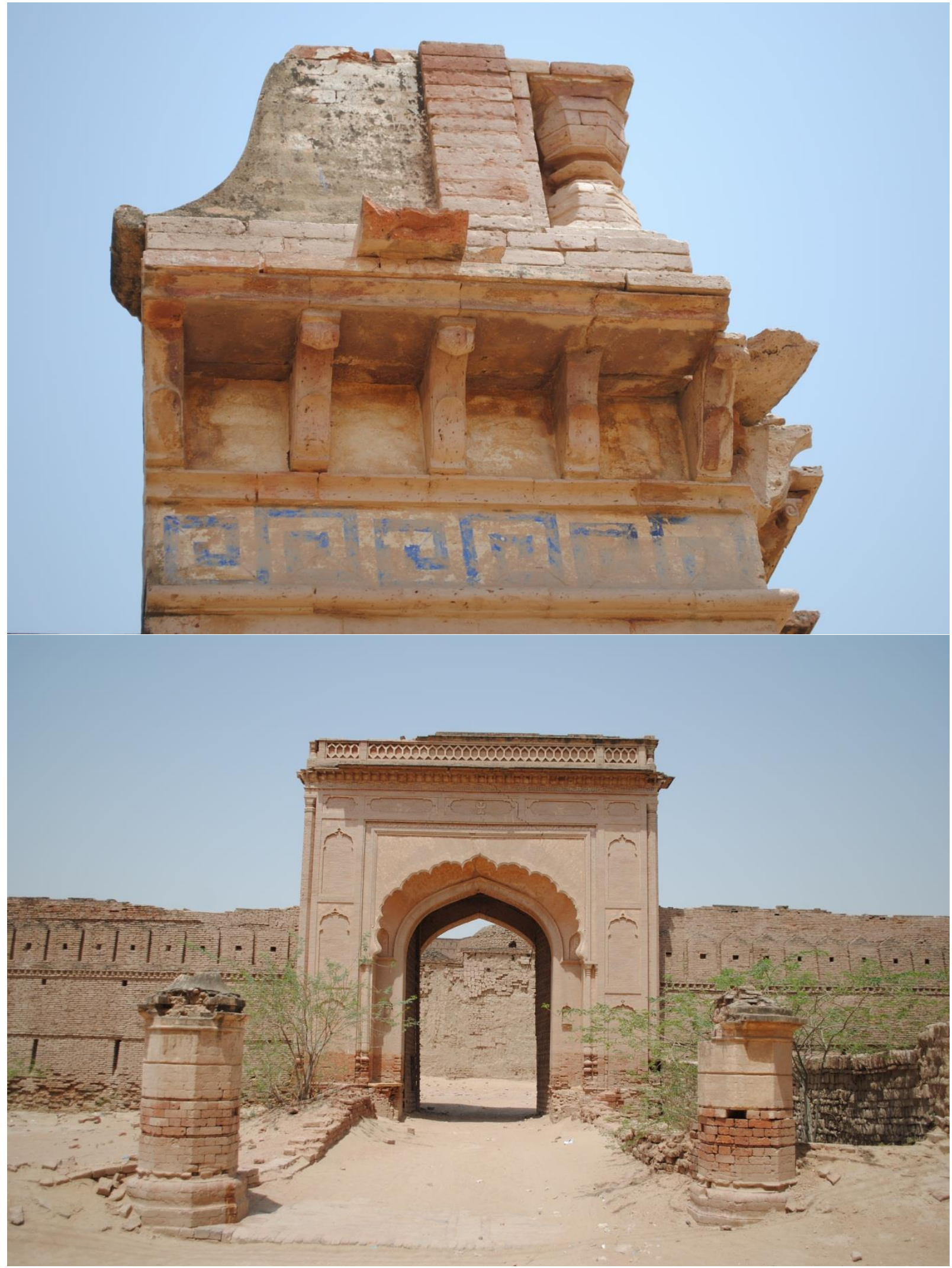

\section{REFERENCES}

[1] Samia Khalid. Derawar through the Ages: A Military and Dynastic History. Ancient Pakistan, Vol. XXVII (2016)

This publication is licensed under Creative Commons Attribution CC BY 
[2] UNESCO. Derawar and the Desert Forts of Cholistan. Government of Pakistan, Directorate General of Archaeology

[3] Derawar Fort: forgotten in time (March, 2018). THE EXPRESS TRIBUNE

[4] Tourism Development Corporation of Pakistan. Cholistan Desert

[5] Derawar and the Desert Forts, Cholistan. Directorate General of Archaeology

[6] Tourism Department, Government of The Punjab

[7] Fazal Khaliq (01 Feb, 2017). Derawar Fort: a 9th century human marvel on the verge of collapse. DAWN

\section{AUTHORS}

First Author - Nusrat Bibi (Assistant Professor), Department of Textile Design, University College of Art \& Design, Faculty of Arts, The Islamia University of Bahawalpur, Pakistan, Mail ID: nusratbibi1987@gmail.com, Cell\# 03008667684 